\title{
Willingness to pay for a new drug delivery in Parkinson patients
}

\author{
This article was published in the following Dove Press journal: \\ Journal of Multidisciplinary Healthcare \\ I October 2014 \\ Number of times this article has been viewed
}

\section{Johan Lökk'1,2 \\ Sara Olofsson ${ }^{3}$ \\ Ulf Persson ${ }^{3}$}

'Department of Neurobiology, Care Sciences and Society, Karolinska Institutet, Stockholm, Sweden; ${ }^{2}$ Geriatric Department, Karolinska University Hospital, Stockholm, Sweden; ${ }^{3}$ The Swedish Institute for Health Economics, Institute for Health Economics (IHE), Lund, Sweden
Correspondence: Johan Lökk Geriatric Department, Karolinska University Hospital, |4| 86 Stockholm, Sweden Email johan.lokk@karolinska.se
Objective: The Swedish reimbursement system operates a system where prices are set based on the expected value to the consumer. This value can be measured using willingness to pay (WTP).

Aim: To assess Parkinson's disease (PD) patients' WTP for newly developed microtablets of levodopa in combination with a drug-delivering electronic device $(\mathrm{M} / \mathrm{E})$ compared to standard treatment with levodopa in combination with the COMT (catechol-O-methyl transferase)inhibitor entacapone (L/e).

Method: A total of 2,000 randomly included PD patients had a postal questionnaire covering demographics, disease-specific issues, views on medication and WTP in different hypothetical scenarios. The first scenario was $\mathrm{M} / \mathrm{E}$ with no change in effects or side effects; the second scenario was $\mathrm{M} / \mathrm{E}$ with same effect and less side effects; and the third scenario was $\mathrm{M} / \mathrm{E}$ with improved effect and less side effects. These scenarios were coupled to different costs to choose from.

Results: A total of 999 patients $(50 \%)$ responded, mean age of 71 years and a mean PD duration of 9 years. Of all respondents, $50 \%$ preferred $\mathrm{M} / \mathrm{E}$ before L/e in scenario one with increasing preference to scenario three. The average monthly WTP among all respondents in scenario one was SEK 230 and SEK 226 in L/e, both with an almost longitudinal doubling up to scenario three. Duration of PD-related symptoms, high education, and high medication intake implied a higher WTP in all scenarios in contrast to age, sex, and extra doses of levodopa.

Conclusion: WTP for M/E increased gradually with high medication intake and education as well as with expected increased reduction of PD symptoms.

Keywords: Parkinson's disease, levodopa, microtablets, WTP

\section{Introduction}

Since the 1960s, levodopa is a pharmacological drug that has been used in the treatment of Parkinson's disease (PD). ${ }^{1}$ Often, the pharmacological treatment of PD is started with levodopa due to its favorable effect and initial few side effects. ${ }^{2}$ Moreover, levodopa is the drug that eventually all patients get, even if starting with other anti-PD drugs. Standard prescription of levodopa is initially performed with tablets corresponding to a successively increasing dose of 50-100 mg three to four times daily. ${ }^{3}$ This dose might sometimes be needed to be increased to a total dose of $600 \mathrm{mg}$ to ascertain an effect on PD symptoms. However, new ways of administering levodopa with the objective of continuous dopaminergic administration has been addressed as an optimal way to mimic the physiological action of dopamine in the brain by having a smoother plasma concentration. ${ }^{4}$ This concept of continuous dopaminergic stimulation has been practically difficult to administer. One way is to fraction levodopa in small doses several 
times a day. ${ }^{5}$ Another way is by adding the enzyme entacapone (Comtess), which prolongs the halftime of levodopa. ${ }^{6}$ The latter mechanism increases the mean "on" time, ie, the time during the day without bradykinesia or hyperkinesia with 1.0-1.7 hours with a corresponding decrease of "off" time. Entacapone is a COMT (catechol-O-methyl transferase)inhibitor, orally administered separately with levodopa or in a fixed combination with levodopa (Stalevo). ${ }^{7}$

A new pharmacological possibility has recently emerged using microtablets containing $5 \mathrm{mg}$ levodopa, enabling highly individual dosage. ${ }^{8}$ These tablets are soluble and dispersible in water. To enable a convenient administration of these tablets, an electronic device has been developed, helping the patient with the medication delivery. This device resembles a preprogrammed smartphone, also having a container for the microtablets. It gives a visual and acoustic reminder to the patient when it is time to take the medication and distributes the actual dose from the incorporated container. Thus, this preprogramming of time and amount of medication makes it possible for the doctor and the patient to individualize, follow, and sustain compliance and persistence. ${ }^{8}$ The combination of microtablets and electronic device has been shown to be as effective as an intake of the combination of levodopa + entacapone (Stalevo) rendering a smooth plasma concentration of levodopa over time. ${ }^{9}$ It has also been shown to have similar pharmacological characteristics as standard treatment with levodopa of today. ${ }^{8,9}$ Thus, this new way of delivering levodopa would offer PD patients especially those with motor complications - another treatment alternative. Moreover, patients do not have to swallow tablets but can instead drink a solution prepared by these microtablets dispersed in water. The unique possibility to individualize the dose of levodopa in multiples of $5 \mathrm{mg}$ enables titrating the lowest possible effective dose in combination with the electronic device thus dispensing tablets and reminding patients to take the drugs in a manner resembling continuous dopaminergic administration. Such an improved administration and dopaminergic stimulation will eventually improve the symptomatic effect and probably decrease side effects. It would naturally also be potentially beneficial for the quality of life of patients in line with the results of an earlier study on PD patients' preferences of treatment. ${ }^{10,11}$ These showed that patients found it hard to swallow tablets as well as to time the intake of tablets. The Swedish Dental and Pharmaceutical Benefits Agency (TLV) decides which prescribed medicinal products are granted reimbursement status in Sweden. The TLV operates a value-based pricing system (VBP) for patent-protected medicinal products.
VBP is a system where prices are set based on the expected value to the consumer. ${ }^{12}$ This value can be measured using willingness to pay (WTP). WTP is the maximum amount that a person is prepared to pay for a commodity and is assumed to reveal the value of the commodity to that person. WTP is elicited by either observing people's behavior on the existing market (revealed preferences) or by asking people about their WTP on a hypothetical market (stated preferences). ${ }^{13}$

To our knowledge there are no published studies on PD patients regarding their WTP for treatments - current, new, or potentially upcoming.

The primary aim of this study was to investigate PD patients' WTP for a new treatment of levodopa with microtablets in combination with an electronic device $(\mathrm{M} / \mathrm{E})$ for drug delivery compared with standard treatment with the combination of levodopa + entacapone (L/e).

The secondary aim was to investigate how side effects and disease severity affect the WTP.

\section{Material}

This is a cross-sectional study using simple random sampling. A sample of individuals with PD was identified from the member registries of the Swedish Parkinson Association. About 5,500 persons with a PD diagnosis are members of the Swedish Parkinson Association, which corresponds to approximately a fourth of all PD patients in Sweden. ${ }^{14}$ A total of 2,000 PD members of the Swedish Parkinson Association were randomly included to have a postal questionnaire with one reminding letter. The data collection was performed during the period March 22-May 24, 2013. This study was primarily aimed at studying the preferences of patients currently receiving treatment with $\mathrm{L} / \mathrm{e}$, since these patients are the potential receivers of $\mathrm{M} / \mathrm{E}$. However, the questionnaire was also sent to patients currently receiving different types of treatment because it was not possible to identify L/e users in the member registry of the Swedish Parkinson Association. For the WTP part - where the respondent is asked to compare $\mathrm{M} / \mathrm{E}$ with $\mathrm{L} / \mathrm{e}$ - these patients were asked to skip the questions or assume that their current treatment had the same characteristics as L/e.

\section{Method}

Eligible patients had a postal delivery of a questionnaire which they were asked to fill in after informed consent. The questionnaire contained questions on demographics, diseasespecific questions, views on their medication (eg, swallowing difficulties, remembering the timing of medication intake), and the WTP for different hypothetical scenarios after having information of the meaning of WTP. 
They were presented with different scenarios where they could choose from a no-cost treatment of L/e and different treatment scenarios with $\mathrm{M} / \mathrm{E}$ (Table 1). The description of effect difference between the two administration types was based on a pharmacokinetic study comparing L/e and $\mathrm{M} / \mathrm{E}$, which earlier has shown a $50 \%$ reduction of plasma fluctuation of levodopa. ${ }^{8,9}$ As there are no direct comparative studies showing differences in effect or side effects between $\mathrm{L} / \mathrm{e}$ and $\mathrm{M} / \mathrm{E}$, three hypothetical scenarios were presented to respondents:

1. M/E implies only a new way of administration and no change in side effects or effect.

2. $\mathrm{M} / \mathrm{E}$ implies a new way of administration, less side effects but same effect.

3. M/E implies a new way of administration, less side effects and improved effect.

Through this design, it would be possible to study the WTP for the three options by presenting them with different costs. ${ }^{15}$
It was assumed that Stockholm County Council as standard procedure paid all if the respondent chose to have L/e. This was estimated to SEK 1,000 (EUR 110) per month. If the respondent chose to have $\mathrm{M} / \mathrm{E}$, it was assumed that the extra cost was to be paid by the patient himself. Then five questions were posed to the respondents in order to investigate the willingness to pay for M/E (Table 1). To ensure that the WTP question would deliver valid answers, we applied methods which have been shown to reduce biases common in this type of study (eg, hypothetical bias and starting point bias), including the card-sorting procedure (question $\mathrm{C}$, Table 1), and certainty calibration for payers (question E, Table 1). ${ }^{13,16}$

The results are presented for all respondents and for the subgroup currently receiving $\mathrm{L} / \mathrm{e}$ respectively.

An ordinary least squares regression is performed to assess whether WTP is significantly positively related to income. This is a validity test of WTP studies. The WTP was logarithmically transformed due to the skewness of the WTP data.

Table I Example of hypothetical willingness to pay scenario

Situation I. A new type of drug delivery

Assume that your doctor tells you that there is a new version of levodopa. This version means a new type of drug delivery. You take microtablets containing $5 \mathrm{mg}$ levodopa per tablet using an electronic device which makes it possible to adjust the dose individually.

Also assume that the county council pays the entire cost of your current treatment. The county council will pay the same amount for the new version of levodopa, but since the new version is more expensive you need to pay the additional cost out-of-pocket.

\section{Your current drug containing levodopa (Stalevo/Comtess)}

[A picture of Stalevo tablets were included]

Price: county council pay

(approximately SEKI,000/month)

I. You take your pills approximately 3-4 times per day. One pill contains between 25 and $200 \mathrm{mg}$ levodopa.

2. You bring your pills with you during the day in a tablet container or dose-dispenser.

3. You need to remember when it is time to take your medication.

4. You take your pill by swallowing it with a glass of water.

5. You need to remember when you have taken your pill, eg, by using a dose-dispenser or by making a note.

A. What treatment do you prefer?

B. Would you be prepared to pay something to receive treatment with microtablets and electronic device?

C. Given your household's current income, what is the highest amount you would be prepared to pay per month to receive your treatment with microtablets and electronic device instead of your current treatment with Stalevo/Comtess? To help you answer this question, eight different amounts are presented below in a random order. Indicate for each amount whether you would be willing to pay the amount, if you are unsure/don't know, or if you are not willing to pay the amount. Amounts presented: SEK80, SEK800, SEK300, SEK50, SEK3,000, SEKI0, SEKI,500, SEKI per month.

D. What is the highest amount you would be willing to pay to receive microtablets and electronic device instead of Stalevo/Comtess?

E. How certain are you that you would pay this amount for microtablets and electronic device?

The new version of levodopa (microtablets in combination with an electronic device) [A picture of microtablets and electronic device were included] Price: you pay the additional cost

I. You take your pills approximately 6-8 times per day. One pill contains $5 \mathrm{mg}$ levodopa, which means that you can adjust your dose more precisely.

2. You bring your pills with you during the day in the electronic device which you can attach to your belt or put in your pocket or bag.

3. The electronic device reminds you when it is time to take your medication by making a sound, light, and/or vibration, and distributes the dose from the incorporated container.

4. You put your pills (5-20 pills) in an ordinary cup or glass of water. The pills are dispersed in 10 seconds and you drink the solution.

5. The electronic device records when you have taken your pills, what dose you took, and you are able to use the device to register your health.

6. You need to load the batteries for the electronic device at least everyother night. 
Monetary values are expressed in SEK. For reference, as of the year 2012, EUR 1= SEK 9.

The Regional Ethical Committee of Lund, Sweden provided an advisory statement where no impediments for the study could be found from an ethical standpoint.

Table 2 Demographics and personal characteristics of the responders

\begin{tabular}{|c|c|c|}
\hline \multirow[t]{2}{*}{ Characteristic } & \multicolumn{2}{|c|}{ Proportion (\%) } \\
\hline & $\begin{array}{l}\text { All } \\
(n=999)\end{array}$ & $\begin{array}{l}\text { Using } \\
\text { entacapone } \\
(n=344)\end{array}$ \\
\hline \multicolumn{3}{|l|}{ Sex } \\
\hline Woman & 42.14 & 37.79 \\
\hline Man & 57.56 & 62.21 \\
\hline No answer & 0.30 & 0.00 \\
\hline \multicolumn{3}{|l|}{ Age } \\
\hline$>30$ years & 0.10 & 0.00 \\
\hline 30-39 years & 0.20 & 0.29 \\
\hline $40-49$ years & 1.00 & 1.74 \\
\hline $50-59$ years & 5.61 & 6.98 \\
\hline $60-69$ years & 31.93 & 37.50 \\
\hline $70-79$ years & 47.05 & 41.86 \\
\hline$\leq 80$ years & $13.6 \mid$ & 11.63 \\
\hline No answer & 0.50 & 0.00 \\
\hline \multicolumn{3}{|c|}{ Number of adults in household } \\
\hline 1 & 26.33 & 25.87 \\
\hline 2 & 68.47 & 68.90 \\
\hline 3 or more & 3.50 & 4.07 \\
\hline No answer & 1.70 & 1.16 \\
\hline \multicolumn{3}{|c|}{ Number of children in household } \\
\hline None & 97.00 & 96.22 \\
\hline I or more & 1.90 & 1.45 \\
\hline No answer & 1.10 & 1.16 \\
\hline \multicolumn{3}{|l|}{ Education } \\
\hline Elementary school & 28.93 & 23.55 \\
\hline High school & 28.23 & 28.20 \\
\hline University & 34.23 & 40.41 \\
\hline Other & 5.31 & 4.36 \\
\hline No answer & 3.30 & 3.49 \\
\hline \multicolumn{3}{|l|}{ Occupation } \\
\hline Employed & 5.61 & 7.27 \\
\hline Retired & 82.08 & 78.78 \\
\hline Sick leave & 5.51 & 6.69 \\
\hline Unemployed & 0.20 & 0.58 \\
\hline Self-employed & 2.10 & 2.33 \\
\hline Other & 0.90 & 0.87 \\
\hline No answer & 3.60 & 3.49 \\
\hline \multicolumn{3}{|c|}{ Household income (SEK/month) } \\
\hline$>19,900$ & 18.42 & 16.86 \\
\hline $20,000-29,900$ & 22.02 & 23.84 \\
\hline $30,000-39,900$ & 19.82 & 17.73 \\
\hline $40,000-49,900$ & 10.91 & 13.37 \\
\hline $50,000-59,900$ & 5.51 & 6.10 \\
\hline $60,000-69,900$ & 2.40 & 2.62 \\
\hline $70,000-79,900$ & 1.90 & 2.03 \\
\hline$\leq 80,000$ & 1.60 & 2.62 \\
\hline Prefer not to answer & 11.91 & 8.43 \\
\hline No answer & 5.51 & 6.40 \\
\hline
\end{tabular}

Table 3 Disease and treatment characteristics of the responders

Characteristic

Proportion (\%) or average (SD)

\begin{tabular}{lll} 
& \multicolumn{2}{l}{ average (SD) } \\
\cline { 2 - 3 } & $\begin{array}{l}\text { All } \\
(\mathbf{n = 9 9 9 )}\end{array}$ & $\begin{array}{l}\text { Using } \\
\text { entacapone } \\
(\mathbf{n}=\mathbf{3 4 4})\end{array}$ \\
\hline $\begin{array}{l}\text { Disease duration (years) } \\
\text { Disease severity }\end{array}$ & $9.0 \mathrm{I}(6.4 \mathrm{I})$ & $10.49(6.03)$
\end{tabular}

Moderate

$19.52 \quad 16.28$

Severe

No information

60.36

62.21

Drugs used for treatment of Parkinson

$18.52 \quad 19.77$

Madopark

1.60

1.74

Sinemet

$52.35 \quad 36.34$

Madopar quick

23.22

15.99

Comtess

58.72

Stalevo

48.25

31.10

Azilect

I0.7|

70.64

Sifrol

Sifrol depot

29.65

Requip

Requip depot

Other

22.62

26.16

$\begin{array}{ll}26.93 & 26.16 \\ 17.32 & 19.77\end{array}$

$\begin{array}{ll}4.70 & 6.98\end{array}$

$11.31 \quad 14.83$

Treatment start for levodopa

2013

23.32

24.42

2012

2011

2010

2009 or earlier

No information

Levodopa dose per day

$0-100 \mathrm{mg}$

$101-200 \mathrm{mg}$

$20 \mathrm{I}-300 \mathrm{mg}$

$30 \mathrm{I}-400 \mathrm{mg}$

$40 \mathrm{I}-500 \mathrm{mg}$

More than $500 \mathrm{mg}$

No information

1.00

0.87

5.41

2.62

5.81

8.61

63.86

3.20

6.10

61.05

$15.32 \quad 26.16$

Treatment start for entacapone

2013

2012

$|4.4|$

21.22

8.71

6.98

9.61

5.52

$11.71 \quad 7.27$

$10.91 \quad 4.36$

$21.92 \quad 17.73$

$22.72 \quad 36.92$

2011

2.10

4.94

2010

2009 or earlier

3.00

8.14

3.90

10.47

4.30

12.21

No information

22.52

59.88

Number of extra doses of levodopa per day

$1 \quad 13.51$

4.36

46.22

3

4

5 or more

2.40

17.44

8.43

No information

0.60

$1.20 \quad 0.58$

Total number of tablets per day

Assistance when taking medicine

$\begin{array}{lll}\text { No assistance } & 74.77 & 72.67\end{array}$

$\begin{array}{lll}\text { Assistance by relative/friend } \quad 15.5 \mid & 16.57\end{array}$

Assistance by professional caretaker $\quad 9.01 \quad 10.47$

No information

0.70

0.29

(Continued) 
Table 3 (Continued)

\begin{tabular}{lll}
\hline Characteristic & \multicolumn{2}{l}{$\begin{array}{l}\text { Proportion (\%) or } \\
\text { average (SD) }\end{array}$} \\
\cline { 2 - 3 } & $\begin{array}{l}\text { All } \\
(\mathbf{n = 9 9 9 )}\end{array}$ & $\begin{array}{l}\text { Using } \\
\text { entacapone } \\
(\mathbf{n}=\mathbf{3 4 4})\end{array}$ \\
\hline Medical device & & \\
None & 39.44 & 35.76 \\
Dosage unit & 24.12 & 22.97 \\
Alarm & 18.62 & 19.77 \\
Dosage unit and/or alarm & 10.01 & 13.08 \\
Other & 6.01 & 6.98 \\
No information & 1.80 & 1.45 \\
\hline
\end{tabular}

Abbreviation: SD, standard deviation.

\section{Results}

Of the 2,000 PD patients included in the study, 999 (50\%) responded with a completed questionnaire. Of these, $344(34 \%)$ stated that they were treated with L/e. The mean age was 71 years, with $58 \%$ men. The distribution of age and sex of the respondents corresponded to that of the whole patient population. ${ }^{14}$ Over $80 \%$ of the respondents were retired, and the median monthly income in the household was between SEK 30,000 and SEK 39,900 (EUR 3,300-4,210) (Table 2). The mean PD duration was 9 years, and $78 \%$ stated their disease to be moderate to severe (Table 3). One out of four reported need of help taking medicines, and three out of five used some sort of device as a medication reminder. Respondents on L/e had longer disease duration, more severe disease, less levodopa use, and more need of assistance compared with the whole group. Almost $85 \%$ of them also stated PD-related symptoms during the day compared with $78 \%$ of those without $\mathrm{L} / \mathrm{e}$, however with less reports of symptoms more than 2 hours a day and $6 \%$ more reports of no symptoms (Figure 1).

Of all respondents, $50 \%$ preferred $\mathrm{M} / \mathrm{E}$ before $\mathrm{L} / \mathrm{e}$ in scenario one (new way of administration). As expected, an increase of respondents preferred $\mathrm{M} / \mathrm{E}$ in scenario two (new way of administration and less side effects) as well as in scenario three (new way of administration, less side effects and better effect). Respondents already on L/e were less prone to have $\mathrm{M} / \mathrm{E}$ (Figure 2).

The average monthly WTP among all respondents and those on L/e in scenario one was SEK 230 and SEK 226, respectively; SEK 252 and SEK 256, respectively, in scenario two; and SEK 396 and SEK 436, respectively, in scenario three (Table 4 and Figure $3 \mathrm{~A}-\mathrm{C}$ ). The WTP was positively correlated to the respondents income in scenarios two and three but not in scenario one (Tables 5-7). An increase in income per consumption unit by SEK 1, 000 per month will increase WTP in scenario three by $2.77 \%$, everything else held constant. However, age, sex, or extra doses of levodopa were not significantly correlated to WTP.

The views having most impact on WTP in scenario one were control of medication intake, and swallowing problems. Having PD-related symptoms, high education and medication

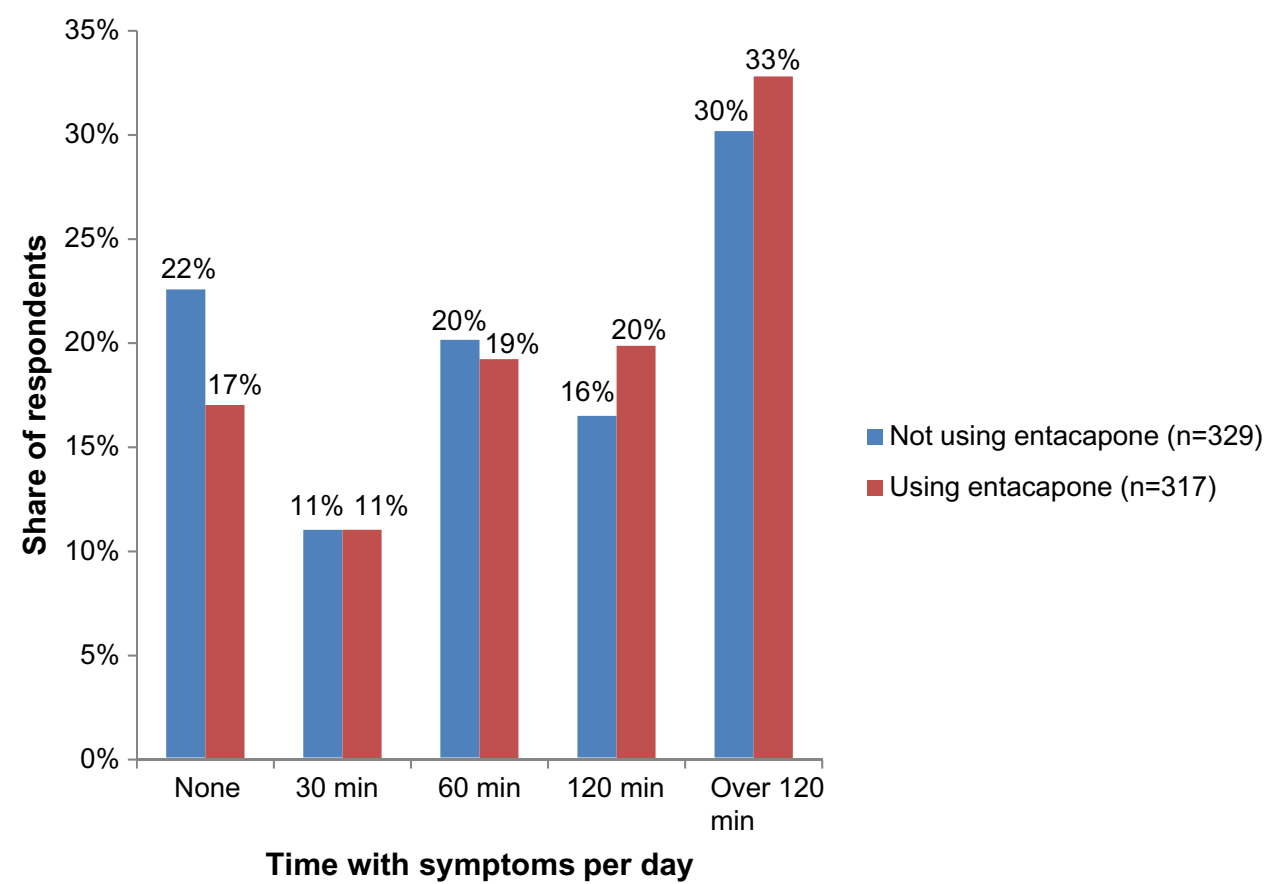

Figure I Time with symptoms per day for respondents using and not using entacapone. Abbreviation: min, minutes. 


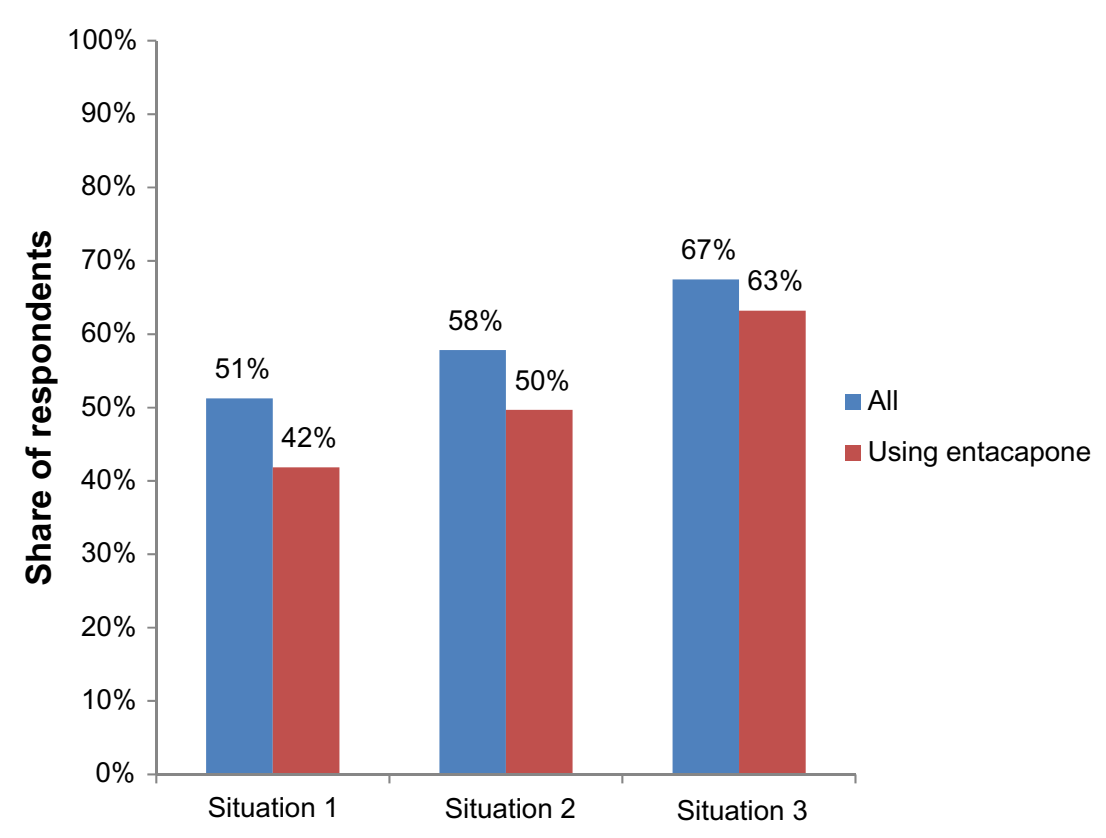

Figure 2 Proportion of respondents who prefer microtablets and electronic dispenser to Stalevo/Comtess.

Notes: For situation I, the number of all respondents was 636; and the number of respondents using entacapone was 30 I. For situation 2 the number of all respondents was 645; and the number of respondents using entacapone was 308. For situation 3 the number of all respondents was 624 ; and the number of respondents using entacapone was 296.

intake as well as side effects with diarrhea or pain also implied a higher WTP in all scenarios.

\section{Discussion}

The WTP for this new type of drug-delivery administration with $\mathrm{M} / \mathrm{E}$ was estimated to SEK 230 per month in all respondents and SEK 226 per month in patients on L/e. It was increased to double that amount if the new treatment also implied a decreased risk of side effects and reduction of symptoms by $50 \%$. Those patients on $\mathrm{L} / \mathrm{e}$ were less prone to prefer $\mathrm{M} / \mathrm{E}$ than those who were not. However, those on L/e had a higher WTP if they were to choose M/E but having L/e per se was not significantly increasing the WTP. However, this was the case in all scenarios when having more PD symptoms and high medication intake and education level but not age, sex, or side effects. As expected, and according to economic theory, the higher the price was for $\mathrm{M} / \mathrm{E}$, the lower the share of respondents WTP. Also, according to economic theory, a higher WTP, the more advantages there were of M/E, ie, the WTP increased from scenario one to scenario three. The income was not significantly related to the WTP in scenario one but in scenario two and three they were significantly related.

Around $30 \%$ of all respondents did not provide any answers to the WTP part. However, all of these respondents

Table 4 Mean WTP in SEK per month (SD) for microtablets and electronic dispenser, of all patients and L/e patients in situations I, 2 , and 3 , respectively

\begin{tabular}{|c|c|c|c|c|c|c|}
\hline & \multicolumn{2}{|c|}{$\begin{array}{l}\text { Situation I } \\
\text { (administration) }\end{array}$} & \multicolumn{2}{|c|}{$\begin{array}{l}\text { Situation } 2 \\
\text { (administration } \\
\text { and side effects) }\end{array}$} & \multicolumn{2}{|c|}{$\begin{array}{l}\text { Situation } 3 \\
\text { (administration, side } \\
\text { effects, and better effect) }\end{array}$} \\
\hline & $\mathbf{n}$ & WTP & $\mathbf{n}$ & WTP & $\mathbf{n}$ & WTP \\
\hline \multicolumn{7}{|l|}{ All respondents } \\
\hline Definitely sure & 159 & $440(560)$ & 166 & $490(612)$ & 208 & $661(1,065)$ \\
\hline Probably sure & 192 & 419 (591) & 189 & $4 \mid 4(574)$ & 209 & $532(702)$ \\
\hline Total & 688 & $230(468)$ & 662 & $252(49 I)$ & 660 & $396(780)$ \\
\hline \multicolumn{7}{|c|}{ Using entacapone, L/e } \\
\hline Definitely sure & 140 & $296(464)$ & 142 & $370(549)$ & 158 & $546(742)$ \\
\hline Probably sure & 134 & 339 (659) & 125 & $343(639)$ & $|3|$ & $54 \mid(816)$ \\
\hline Total & 298 & $226(505)$ & 293 & $256(530)$ & 293 & $436(764)$ \\
\hline
\end{tabular}

Abbreviations: WTP, willingness to pay; SD, standard deviation; L/e, levodopa/entacapone. 
A

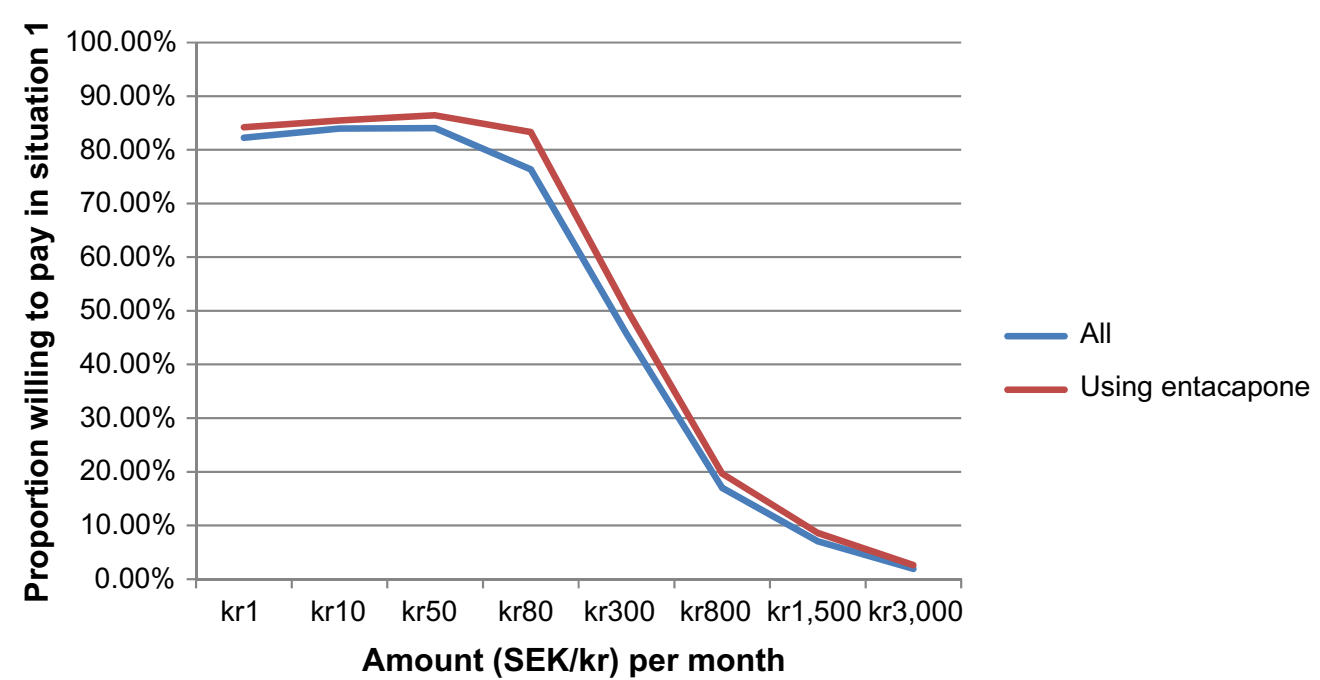

B

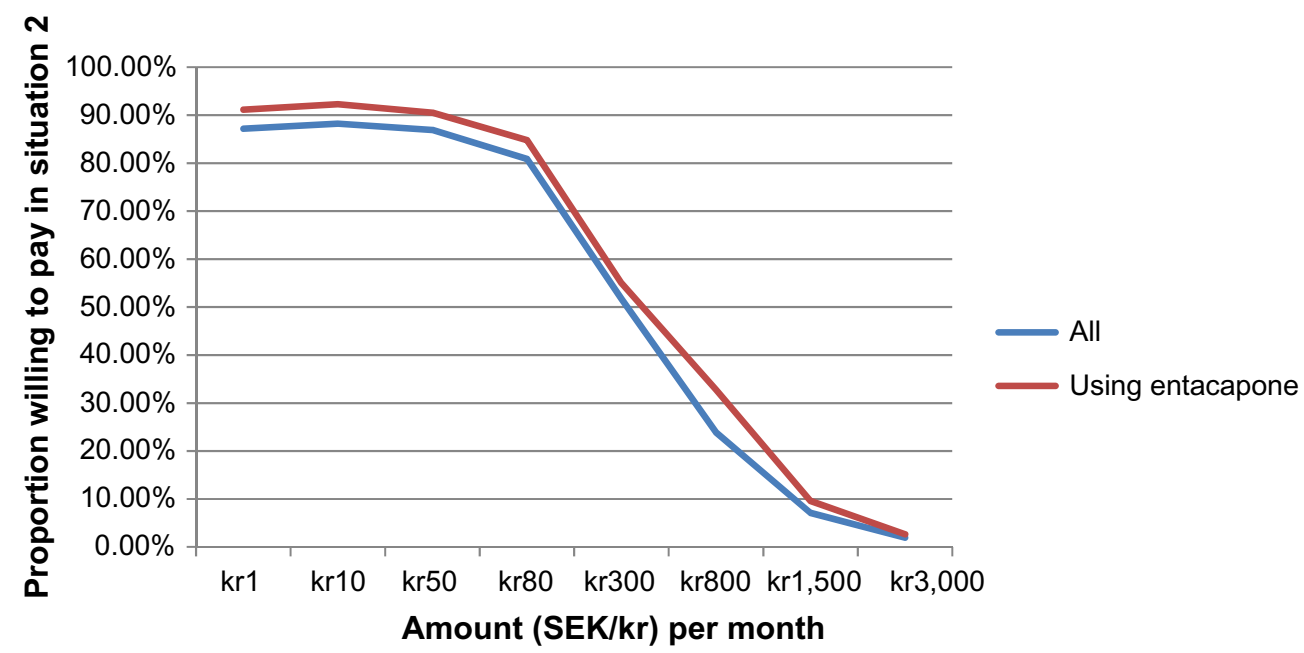

C

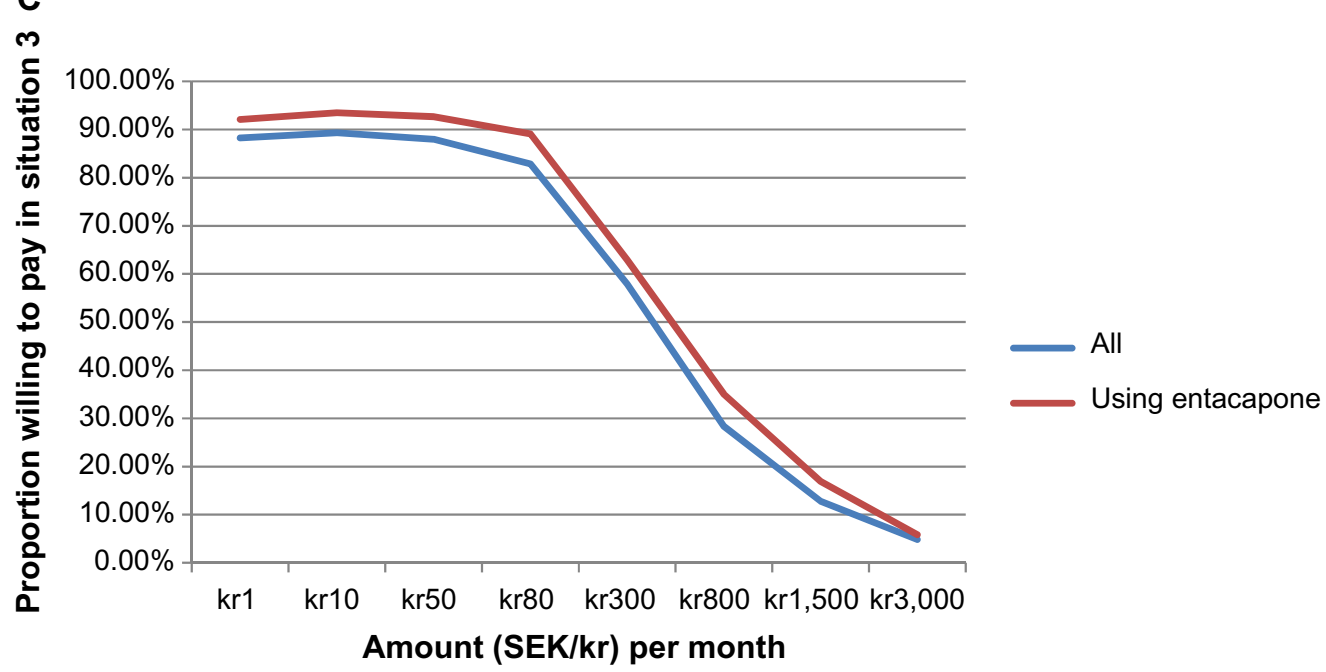

Figure 3 Demand curves for microtablets and electronic dispenser in situation I (A), situation 2 (B), and situation 3 (C) among all respondents and among respondents using entacapone. 
Table 5 Regression of log WTP in situation I (new administration), $\mathrm{n}=177$

\begin{tabular}{lllll}
\hline Parameter & Coefficient & \multicolumn{2}{c}{$95 \%$ Cl } & $P$-value \\
\hline Constant & 4.38755 & 2.914982 & 5.860118 & $0.000^{*}$ \\
Age & -0.0367831 & -0.2566623 & 0.183096 & 0.742 \\
$\begin{array}{l}\text { Female } \\
\text { University }\end{array}$ & -0.1572513 & -0.5486239 & 0.2341213 & 0.429 \\
education & 0.4465399 & 0.0560744 & 0.8370054 & $0.025^{*}$ \\
$\begin{array}{l}\text { Income per CU } \\
\text { Number of extra }\end{array}$ & 0.0000116 & $-4.57 \times 10^{-6}$ & 0.0000278 & 0.158 \\
$\begin{array}{l}\text { doses } \\
\text { Number of tablets }\end{array}$ & 0.0344342 & 0.0040903 & 0.0647782 & $0.026^{*}$ \\
$\begin{array}{l}\text { per day } \\
\text { Receive treatment }\end{array}$ & 0.1370892 & -0.3722956 & 0.646474 & 0.596 \\
$\begin{array}{l}\text { assistance } \\
\begin{array}{l}\text { Number of side } \\
\text { effects }\end{array}\end{array}$ & -0.029165 & -0.1655115 & 0.1071815 & 0.673 \\
$\begin{array}{l}\text { Time with } \\
\text { symptoms per day }\end{array}$ & 0.1498107 & 0.138144 & 0.285807 & $0.03 I^{*}$ \\
$\begin{array}{l}\text { Definitely sure } \\
\text { on WTP }\end{array}$ & 0.009582 & -0.3597373 & 0.3789013 & 0.959 \\
$\begin{array}{l}\text { Using entacapone } \\
\text { Note }\end{array}$ & -0.0667532 & -0.4645906 & 0.3310842 & 0.741 \\
\hline
\end{tabular}

Note: *Statistically significant.

Abbreviations: $\mathrm{Cl}$, confidence interval; $\mathrm{CU}$, consumption unit; WTP, willingness to pay.

were not receiving the treatment that was used as a comparator in the WTP scenario (ie, L/e). These respondents were given the option to skip the WTP part or assume that their current treatment corresponded to $\mathrm{L} / \mathrm{e}$.

A relatively large share of respondents, who responded to the WTP part, preferred L/e to M/E. The reason for this

Table 6 Regression of log WTP in situation 2 (new administration and less side effects), $\mathrm{n}=186$

\begin{tabular}{|c|c|c|c|c|}
\hline Parameter & Coefficient & $95^{\circ}$ & $6 \mathrm{Cl}$ & $P$-value \\
\hline Constant & 4.611491 & 3.205429 & 6.017554 & $0.000^{*}$ \\
\hline Age & -0.0809476 & -0.2893662 & $0.12747 \mid 1$ & 0.444 \\
\hline Female & -0.2910966 & -0.6548995 & 0.0727064 & 0.116 \\
\hline $\begin{array}{l}\text { University } \\
\text { education }\end{array}$ & 0.4970584 & 0.1233883 & 0.8707285 & $0.009 *$ \\
\hline Income per CU & 0.0000146 & $-2.23 \times 10^{-7}$ & 0.0000295 & $0.054^{*}$ \\
\hline $\begin{array}{l}\text { Number of extra } \\
\text { doses }\end{array}$ & -0.0304492 & -0.1897021 & 0.1288037 & 0.706 \\
\hline $\begin{array}{l}\text { Number of tablets } \\
\text { per day }\end{array}$ & 0.0323439 & $0.003804 I$ & 0.0608836 & $0.027^{*}$ \\
\hline $\begin{array}{l}\text { Receive treatment } \\
\text { assistance }\end{array}$ & 0.1328528 & -0.3280093 & $0.5937 \mid 49$ & 0.570 \\
\hline $\begin{array}{l}\text { Number of side } \\
\text { effects }\end{array}$ & -0.0488867 & -0.1721462 & 0.0743727 & 0.435 \\
\hline $\begin{array}{l}\text { Time with } \\
\text { symptoms per day }\end{array}$ & 0.1986523 & 0.0631505 & 0.3341542 & $0.004 *$ \\
\hline $\begin{array}{l}\text { Definitely sure } \\
\text { on WTP }\end{array}$ & 0.1560748 & -0.1963221 & 0.5084717 & 0.383 \\
\hline Using entacapone & -0.2733764 & -0.6397526 & 0.0929998 & 0.143 \\
\hline
\end{tabular}

Note: *Statistically significant.

Abbreviations: $\mathrm{Cl}$, confidence interval; $\mathrm{CU}$, consumption unit; WTP, willingness to pay.
Table 7 Regression of log WTP in situation 3 (new administration, less side effects, and a better effect), $n=219$

\begin{tabular}{|c|c|c|c|c|}
\hline \multirow{2}{*}{$\begin{array}{l}\text { Parameter } \\
\text { Constant }\end{array}$} & \multirow{2}{*}{$\begin{array}{l}\text { Coefficient } \\
4.08886\end{array}$} & \multicolumn{2}{|c|}{$95 \% \mathrm{Cl}$} & \multirow{2}{*}{$\frac{P \text {-value }}{0.000^{*}}$} \\
\hline & & 2.780499 & 5.397221 & \\
\hline Age & -0.0410659 & -0.234199 & 0.1520672 & 0.676 \\
\hline Female & -0.3313815 & $-0.677 \mid 363$ & 0.0143734 & 0.060 \\
\hline $\begin{array}{l}\text { University } \\
\text { education }\end{array}$ & 0.4210315 & 0.0700388 & 0.7720242 & $0.019 *$ \\
\hline Income per CU & 0.0000277 & 0.0000124 & 0.0000429 & $0.000 *$ \\
\hline $\begin{array}{l}\text { Number of extra } \\
\text { doses }\end{array}$ & -0.032505 I & -0.1821974 & 0.1171873 & 0.669 \\
\hline $\begin{array}{l}\text { Number of tablets } \\
\text { per day }\end{array}$ & $0.043 \mid 283$ & 0.0161861 & 0.0700705 & $0.002 *$ \\
\hline $\begin{array}{l}\text { Receive treatment } \\
\text { assistance }\end{array}$ & 0.0086193 & -0.438303 & 0.4555416 & 0.970 \\
\hline $\begin{array}{l}\text { Number of side } \\
\text { effects }\end{array}$ & $-0.063356 \mathrm{I}$ & -0.1832409 & 0.565287 & 0.299 \\
\hline $\begin{array}{l}\text { Time with } \\
\text { symptoms per day }\end{array}$ & 0.280983 & 0.1515231 & 0.4104429 & $0.000 *$ \\
\hline $\begin{array}{l}\text { Definitely sure } \\
\text { on WTP }\end{array}$ & -0.1869365 & -0.5176378 & 0.1437647 & 0.266 \\
\hline Using entacapone & -0.0931787 & -0.4454576 & 0.2591003 & 0.603 \\
\hline
\end{tabular}

Note: *Statistically significant.

Abbreviations: $\mathrm{Cl}$, confidence interval; $\mathrm{CU}$, consumption unit; WTP, willingness to pay.

is unclear since the survey was not designed to elicit this. One reason might be that the respondents are not technology accustomed given the high mean age, and consequently skeptical of an electronic device in drug delivery. Also, the $\mathrm{M} / \mathrm{E}$ treatment requires more frequent administration compared with L/e.

The description of the M/E treatment in the WTP scenarios was very specific, and the generalizability of the WTP estimate of this study is limited.

The survey is a contingent valuation study. This means that the respondent is presented with a change in a non-market good or service and asked what she or he would be willing to pay for this change. An alternative approach is choice experiment/discrete choice where the respondent is presented with a series of alternatives that varies according to certain characteristics - including cost - and asked to choose her/his most preferred. The contingent valuation approach provides an estimate of the WTP for the total value of the product, while the discrete choice approach provides an estimate of the WTP for individual attributes (such as convenience, single medication, route of administration, and safety). A limitation of the chosen design is therefore that it does not explicitly allow the identification of the drivers of the WTP. However, the design still allows some drivers to be identified implicitly. The WTP results from the three scenarios indicate the relative importance of convenience, less side effects, and less time with symptoms. Furthermore, the result of the 
regression show that time with symptom is an important driver of the WTP.

Naturally, there is a weakness of this study not having direct comparative studies between $\mathrm{M} / \mathrm{E}$ and L/e regarding effects and side effects. However, this issue was not the aim of this study but would be interesting to investigate in future studies.

A future use of $\mathrm{M} / \mathrm{E}$ might be a complement to the preexisting advanced therapies advocating the continuous dopaminergic stimulation or rather continuous dopaminergic delivery, which both aim at smooth continuous delivery of levodopa or dopamine agonists mimicking physiological processes eventually targeting the disturbed and dopamine depleted brain areas. ${ }^{4}$

Pharmacological treatment of PD has undergone a marvelous development during the last decades with the launch of levodopa in the 1960s to the emergence of the current armamentarium of different drugs - dopamine agonists, enzyme-inhibitors, anticholinergics, apomorfine, and amantadine - targeting different processes of the dopamine metabolism and other processes. ${ }^{17}$ In addition, there are also new advanced therapies addressed for advanced disease patients with drug delivery through pumps or brainsurgery with deep brain surgery. ${ }^{18-22}$ As patients' wellbeing is one of the main purposes with professional health care, it is important to investigate patients' opinions of treatment and care and how they affect their wellbeing. Considering patients' preferences when new treatments are launched is also important in order to assess potential persistence and compliance. There are two studies on PD patients' preferences for a comfortable treatment, ${ }^{10,11}$ where one study reported that patients preferred having their anti-PD drug non-orally (ie, by a patch). ${ }^{10,23}$ The other study showed that most patients preferred having chewable levodopa before standard levodopa due to swallowing difficulties and the easier way of administration. ${ }^{11}$

This is a first of its kind study elucidating the WTP of PD patients for treatments. The results of this study indicate the value that PD patients place on a new treatment in a way that can be directly compared with the cost of that treatment. This allows allocating resources according to patient preferences, which can increase wellbeing and treatment compliance.

Our results point in the same direction as other studies reporting that $\mathrm{PD}$ patients have different preferences regarding their medication. ${ }^{10,11,19}$ In contrast to other studies, this study indicates how high PD patients value a simpler way of administration, less side effects, and better effect through assessing their WTP. Patients' assessment and WTP for new medications as well as their assessment for new ways of drug delivery can be of importance for future strategies in health care policy.

\section{Acknowledgments}

The authors are grateful to the patients for their collaboration in the study.

Funding for this study was provided by Sensidose AB.

\section{Disclosure}

The authors have neither financial disclosures nor conflicts of interest to declare in relation to the content of the paper.

\section{References}

1. Carlsson A. A paradigm shift in brain research. Science. 2009;294 1021-1024.

2. Jankovic J, Poewe W. Therapies in Parkinson's disease. Curr Opin Neurol. 2012;25:433-447.

3. Singer C. Managing the patient with newly diagnosed Parkinson disease. Cleve Clin J Med. 2012;79 Supp1 2:S3-S7.

4. Stocchi F. The therapeutic concept of continuous dopaminergic stimulation (CDS) in the treatment of Parkinson's disease. Parkinsonism Relat Disord. 2009;15 Suppl 3:S68-S71.

5. Müller T. Pharmacokinetic considerations for the use of levodopa in the treatment of Parkinson disease: focus on levodopa/carbidopa/ entacapone for treatment of levodopa-associated motor complications. Clin Neuropharmacol. 2013;36:84-91.

6. Reichmann H, Emre M. Optimizing levodopa therapy to treat wearingoff symptoms in Parkinson' disease: focus on levodopa/carbidopa/ entacapone. Expert Rev Neurother. 2012;12:119-131.

7. Reichmann H, Boas J, Macmahon D, et al. Efficacy of combining levodopa with entacapone on quality of life and activities of daily living in patients experiencing wearing-off type fluctuations. Acta Neurol Scand. 2005;111:21-28.

8. Nyholm D, Ehrnebo M, Lewander T, et al. Frequent administration of levodopa/carbidopa microtablets vs levodopa/carbidopa/entacapone in healthy volunteers. Acta Neurol Scand. 2013;127(2):124-132.

9. Nyholm D, Lewander T, Gomes-Trolin C, et al. Pharmacokinetics of levodopa/carbidopa microtablets versus levodopa/benserazide and levodopa/carbidopa in healthy volunteers. Clin Neuropharmacol. 2012;35:111-117.

10. Fargel M, Grobe B, Oesterle E, Hastedt C, Rupp M. Treatment of Parkinson's disease: a survey of patients and neurologists. Clin Drug Investig. 2007;27:207-218.

11. Nausieda PA, Pfeiffer RF, Tagliati M, Kastenholz KV, DeRoche C, Slevin JT. A multicenter, open-label, sequential study comparing preferences for carbidopa-levodopa orally disintegrating tablets and conventional tablets in subjects with Parkinson's disease. Clin Therap. 2005;27:58-63.

12. Persson U, Svensson J, Pettersson B. A new reimbursement system for innovative pharmaceuticals combining value-based and free market pricing. Appl Health Econ Health Policy. 2012;10(4):217-225.

13. Bateman I, Carson R, Day B, et al. Economic Valuation with Stated Preference Techniques: a manual. Cheltenham: Edward Elgar; 2002.

14. Lökk J, Borg S, Svensson J, Persson U, Ljunggren G. Drug and treatment costs in Parkinson's disease patients in Sweden. Acta Neurol Scand. 2012;125:142-147.

15. Carlsson P, Tinghög G. Läkemedel - När är det rimligt att betala själv? [Swedish: Drugs -when is it reasonable to pay yourself?] Stockholm: SNS Publishing; 2013.

16. Blumenschein K, Blomquist G, Johannesson M, Horn N, Freeman P. Eliciting willingness to pay without bias: evidence from a field experiment. Econ J. 2008;118:114-137. 
17. Worth PF. How to treat Parkinson's disease in 2013. Clin Med. 2013;13:93-96.

18. Pandey S. Parkinson's disease: recent advances. J Assoc Physicians India. 2012;60:30-32.

19. Brotchie J, Jenner P. New approaches to therapy. Int Rev Neurobiol. 2011;98:123-150.

20. Stocchi F. Use of apomorphine in Parkinson's disease. Neurol Sci. 2008;29 Suppl 5:S383-S386.
21. Fernandez HH, Odin P. Levodopa-carbidopa intestinal gel for treatment of advanced Parkinson's disease. Curr Med Res Opin. 2011;27:907-919.

22. Varma TR, Fox SH, Eldridge PR, et al. Deep brain stimulation of the subthalamic nucleus: effectiveness in advanced Parkinson's disease patients previously reliant on apomorphine. J Neurol Neurosurg Psychiatry. 2003;74:170-174.

23. Sprenger FS, Seppi K, Poewe W. Drug safety evaluation of rotigotine. Expert Opin Drug Saf. 2012;11:503-512.

\section{Publish your work in this journal}

The Journal of Multidisciplinary Healthcare is an international, peerreviewed open-access journal that aims to represent and publish research in healthcare areas delivered by practitioners of different disciplines. This includes studies and reviews conducted by multidisciplinary teams as well as research which evaluates the results or conduct of such teams or healthcare processes in general. The journal covers a wide range of areas and welcomes submissions from practitioners at all levels, from all over the world. The manuscript management system is completely online and includes a very quick and fair peer-review system. Visit http://www.dovepress.com/testimonials.php to read real quotes from published authors.

Submit your manuscript here: http://www.dovepress.com/journal-of-multidisciplinary-healthcare-journal 